\title{
Acid-Induced Phosphorus Release from Hydrothermally Carbonized Sewage Sludge
}

\author{
Carla Pérez $^{1,2}$ (1) $\cdot$ Jean-François Boily ${ }^{1} \cdot$ Stina Jansson ${ }^{1} \cdot$ Tomas Gustafsson $^{3} \cdot$ Jerker Fick $^{1}$
}

Received: 17 November 2020 / Accepted: 30 April 2021 / Published online: 16 May 2021

(c) The Author(s) 2021

\begin{abstract}
Phosphorus $(\mathrm{P})$ recovery from P-rich residues is crucial to sustain food and industrial demands globally, as phosphate rock reserves are being depleted. The aim of this study is to investigate the speciation and recovery of $\mathrm{P}$ from hydrochars (HC) of a metal-bearing sewage sludge (SS) produced by hydrothermal carbonization (HTC). We here focus on extractions by acid leaching as $\mathrm{P}$ cannot be directly recovered by HTC due to insoluble metal-P compounds. Acid leaching of SS and HCs was investigated using $\mathrm{H}_{2} \mathrm{SO}_{4}$ and $\mathrm{HCl}$ over a range of leaching times, and explained in terms of how composition affects $\mathrm{P}$ and metal release efficiency. $\mathrm{HTC}$ at 180,215 and $250{ }^{\circ} \mathrm{C}$ showed that $\mathrm{P}$ remained immobilized ( $>75 \%$ of total $\mathrm{P}$ ) in the HCs. More than $95 \%$ was present as inorganic $\mathrm{P}$, and was the direct consequence of the double addition of iron salts in the wastewater treatment plant. Leaching experiments in $2.5 \mathrm{M}$ acid solutions showed that a near complete release of $\mathrm{P}$ could be achieved in HCs, while it was only incomplete in SS (up to 85\%). Lower acid concentrations were ineffective for total P recovery. Treatment temperature exceeding $180^{\circ} \mathrm{C}$ however decreased $\mathrm{P}$ release rates, such that total removal took at least $2 \mathrm{~h}$ of reaction time instead of a few minutes. On the other hand, acid leaching transferred more than $70 \%$ of iron, manganese, copper and zinc into the leachate, necessitating a post-treatment purification process. This work therefore reveals that HC produced at low HTC temperatures could offer promising avenues for time- and energy-efficient P recovery from SS.
\end{abstract}

\section{Graphic Abstract}

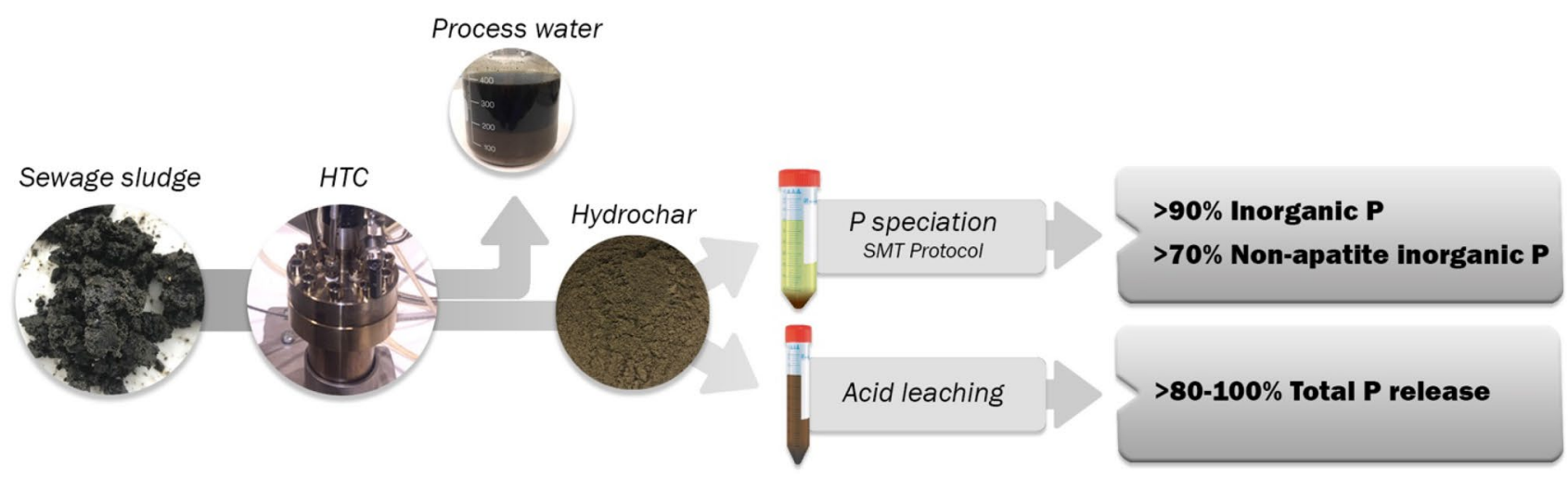

Keywords Digested sewage sludge $\cdot$ Hydrothermal carbonization $\cdot$ Phosphorus release $\cdot$ Acid leaching $\cdot$ Metal release

Carla Pérez

carla.perez@umu.se

Extended author information available on the last page of the article

\section{Statement of Novelty}

The worldwide depletion of phosphate ore worldwide calls for an urgent need to efficiently manage and recycle this essential resource. This study focuses on the use of strong acids for recovering phosphorus after hydrothermal 
carbonization of sewage sludges. Sewage sludges are some of the most phosphorus rich residues available, and this study reveals a path towards a sustainable reuse of these resources. Previous studies have addressed the speciation and recovery of phosphorus during hydrothermal carbonization, yet there is limited knowledge regarding the efficiency of acid leaching of hydrochars from sewage sludges. This study adds novel insight into the benefits of hydrothermal carbonization as strategy to efficiently extract phosphorous form sewage sludge, here using concentrated mineral acids.

\section{Introduction}

Phosphorus $(\mathrm{P})$ is an essential element, and its availability is crucial to sustain food and industrial demands globally. Its main commercial value is as a major component of fertilizers [1]. It is, however, also used in a wide variety of applications and products, such as detergents and paints, as well as food and beverages [2]. Globally, the current growth in the human population is increasing the demand for food, resulting in a rapid increase in $\mathrm{P}$ consumption [3]. While phosphate rock is the only accessible source of $\mathrm{P}[1]$ it is a non-renewable resource from only a handful of countries (Morocco, US, Jordan, China and South Africa), and it is critically approaching near-depletion in the near future [4]. Noting that remaining P sources are of lower quality and/or difficult to extract [5], there is now an urgent need for efficiently managing and recycling of P-rich residues to address the world's future demands.

One potentially important solution is by recovering $\mathrm{P}$ from sewage sludge (SS) in waste streams. SS is the largest by-product generated by municipal Wastewater Treatment Plants (WWTP), and it is an important source of P because of the transfer of phosphate from wastewater into the sludge [6]. While SS includes a mixture of valuable elements (phosphorus, potassium, nitrogen and organic carbon), it may also contains hazardous pollutants (heavy metals, pathogenic microorganisms and organic pollutants) that limit its potential for direct use in agriculture $[7,8]$.

One possible approach to make the nutrients more available is to produce biochars from SS. Biochars are produced by carbonization of the biomaterial in processes such as torrefaction and pyrolysis. In the former, biomaterials are heated to $200-350{ }^{\circ} \mathrm{C}$ under an inert or nitrogen atmosphere [9] while the latter operates in the absence of oxygen at higher temperatures $\left(300-650^{\circ} \mathrm{C}\right)[10]$. However, as SS has a high moisture content of up to 98 weight percent, \% wt., this complicates the direct use of these thermochemical processes, where the moisture content must be $<15 \%$ wt. [11]. High moisture contents even restricts the direct usage in, for example, agriculture and landfill where moisture levels must be $<60 \%$ ) [11].
In contrast to conventional thermochemical processes, hydrothermal carbonization (HTC) is a wet process that uses the inherent water of the sludge as both reactant and solvent under autogenous saturated pressures for several hours at temperatures of around $180-250{ }^{\circ} \mathrm{C}[11,12]$. No energy-intensive drying step is needed before HTC processing of the feedstock [13]. These conditions produce a solid hydrochar (HC), alongside a large amount of process water $(\mathrm{PW})$ and a small gas fraction (mainly $\mathrm{CO}_{2}$ ) as by-products [8]. By degrading the feedstock structure during the hydrothermal reaction, HTC can significantly reduce SS volumes by improving its dewaterability and hydrophobicity $[14,15]$.

The potential for P recycling by HTC processing and the distribution of $\mathrm{P}$ within HTC products are mainly determined by the type of feedstock [16]. For example, HTC processing of SS accumulates P in the HC, mainly as inorganic orthophosphate, which is the form most strongly associated with the composition and speciation of metals in the sludge (rich in $\mathrm{Ca}, \mathrm{Al}$ and Fe content) [14]. Studies of microalgae and distillery grains have shown that $100 \%$ of $\mathrm{P}$ is present in the aqueous phase after HTC for $2 \mathrm{~h}$ at $200{ }^{\circ} \mathrm{C}[17,18]$, while $\mathrm{HTC}$ of animal manure between 200 and $250^{\circ} \mathrm{C}$ transfers the majority of the P to the HC [19].

The accumulation of $\mathrm{P}$ in HC from SS is driven by the addition of coagulant in the WWTP, where metal salts, such as aluminum sulfate and iron (III) chloride, are commonly added to remove the $\mathrm{P}$ via precipitation from the wastewater [20]. Inorganic P thereby tends to remain in the $\mathrm{HC}$ within stable metal associations, along with the majority of the heavy metals [12]. Thus, an effective method for dissolving $\mathrm{P}$ trapped in $\mathrm{HC}$ is treatment by mineral acids in solutions of extremely low $\mathrm{pH}$ [19].

The transformation and distribution of P during HTC of SS has been investigated in many recent studies [21-24]. Zhai et al. [24] showed that feedwater $\mathrm{pH}$ affected the $\mathrm{P}$ species of HC from SS. In that study, low $\mathrm{pH}$ conditions transformed apatite $\mathrm{P}$ into non-apatite $\mathrm{P}$ and organic $\mathrm{P}$ into inorganic $\mathrm{P}$. Alkaline conditions, on the other hand, transformed non-apatite $\mathrm{P}$ to apatite $\mathrm{P}$, and a small fraction of inorganic $\mathrm{P}$ to organic $\mathrm{P}$. These studies have, however, mainly focused on improving the efficiency of total phosphorus (TP) recovery. For example, Becker et al. [12] developed a P recovery approach from SS by HTC using acid leaching of HC with 82.5 wt.\%. of $\mathrm{P}$ recovered as struvite. Although these studies address $\mathrm{P}$ speciation and recovery under specific HTC (e.g., temperature, time, $\mathrm{pH}$ ) and acid leaching conditions, the kinetics of phosphorus and of concomitant (heavy) metal ion release of hydrothermally carbonized SS materials need to be understood.

The principal objective of this investigation is to evaluate the efficiency and time of P release from sewage sludge via HTC followed by acid leaching. HCs generated at three different temperatures $\left(180,215,250^{\circ} \mathrm{C}\right)$ were characterized 
to determine the major inorganic elements present and the distribution of the $\mathrm{P}$. The acid leaching efficiency of dissolving the $\mathrm{P}$ and major multivalent metals was compared with two strong acids $\left(\mathrm{H}_{2} \mathrm{SO}_{4}, \mathrm{HCl}\right)$ at different concentrations $(0.25 \mathrm{M}, 2.5 \mathrm{M})$, and with different extraction times of up to $72 \mathrm{~h}$. In addition, the influence of HTC reaction temperatures on $\mathrm{HC}$ yield, ash content, heavy metal distribution and $\mathrm{HC}$ morphology were examined.

\section{Materials and Methods}

\section{Digested Sewage Sludge}

A digested and mechanically dewatered SS sample was collected from an anaerobic digester receiving activated sludge and primary sludge. The SS was collected in May 2019 from the wastewater treatment plant Vatten och Avfallskompetens $i$ Norr AB (Vakin) (Ön, Umeå, Sweden). It was collected on a single occasion, during stable operating conditions, then packed in a sealed plastic bag and frozen to $-18{ }^{\circ} \mathrm{C}$ within $2 \mathrm{~h}$. The plant used ferric salt $\left(\mathrm{FeCl}_{3}\right)$ as coagulant, before the primary settlement and then after the activated sludge step before the secondary settlement. The sample had a moisture content of $70.9 \mathrm{wt} . \%$ and an ash content of 43.1 wt.\% (dry basis).

\section{Hydrothermal Carbonization}

HTC runs of the digested SS were performed in a $450 \mathrm{~mL}$ stirred stainless steel reactor (Büchiglasuster, Switzerland). The reactor was loaded with a slurry made from $126 \pm 0.74 \mathrm{~g}$ wet SS and $209 \pm 1.4 \mathrm{~g}$ deionized water. The addition of water was added to favor the carbonization process and to promote the proper mixture/stirring of the material. The HTC runs were carried out at three different temperatures $\left(180,215,250^{\circ} \mathrm{C}\right)$ under autogenous pressure, with a holding time of $2 \mathrm{~h}$ and at a mixing speed of $1000 \mathrm{rpm}$. The reactor reached the set temperature in 40-70 $\mathrm{min}$ at heating rates of $5{ }^{\circ} \mathrm{C} / \mathrm{min}$. After the reaction was completed, the reactor was cooled with water for $30-60$ min to bring it back to room temperature. Before each run, the reactor was charged with $\mathrm{N}_{2}$ gas above 40 bars to check leaks.

After each run, the gas product was released and the reactor opened. The solid and liquid fractions were separated using vacuum filtration. $\mathrm{HC}$ was oven-dried overnight at $105{ }^{\circ} \mathrm{C}$, ground and sieved to a particle size of $<0.5 \mathrm{~mm}$, and kept in a desiccator until further use. Liquid fractions were kept at $-18{ }^{\circ} \mathrm{C}$ until subsequent characterization. The hydrochar ( $\mathrm{HC}$ ) and process water (PW) were respectively labelled as HC- $t$ and PW- $t$, where $t$ denotes the HTC temperature in ${ }^{\circ} \mathrm{C}$. All HTC runs were performed in triplicate.

\section{Acid Leaching}

Kinetic acid leaching of SS and HC was performed in $15 \mathrm{ml}$ polypropylene tubes following a procedure similar to that described by Stark et al. [25]. A $0.5 \mathrm{~g}$ sample was mixed in $10 \mathrm{ml} 2.5 \mathrm{M}$ of sulphuric acid $\left(\mathrm{H}_{2} \mathrm{SO}_{4}\right)$ or $10 \mathrm{ml} 2.5 \mathrm{M}$ of hydrochloric acid $(\mathrm{HCl})$ at room temperature. All samples were vigorously mixed with a vortex shaker for 15-20 s, then shaken at predetermined intervals over a period of $5 \mathrm{~min}$ to $72 \mathrm{~h}$. The samples were then centrifuged at 6842 RCF (4500 rpm, Mega Star 1.6R) for 20 min to allow solid-liquid separation. Leachates were collected and stored at $4{ }^{\circ} \mathrm{C}$ before analysis, while solid residues were washed three times with milliQ water, dried at $80^{\circ} \mathrm{C}$ overnight and stored until chemical analysis. For comparison, acid leaching of $\mathrm{HC}$ at $180^{\circ} \mathrm{C}$ (HC-180) was also performed with $0.25 \mathrm{M}$ $\mathrm{H}_{2} \mathrm{SO}_{4}$. Leachate samples were labelled as $\mathrm{L}-t$-acid and the solid residues after leaching as HC-t-acid, where $t$ is the hydrothermal temperature in ${ }^{\circ} \mathrm{C}$ and acid is either $\mathrm{H}_{2} \mathrm{SO}_{4}$ or $\mathrm{HCl}$ at a concentration of $2.5 \mathrm{M}$ or $0.25 \mathrm{M}$.

The time-dependent masses of $\mathrm{P}(\mathrm{mg} / \mathrm{g})$ normalized for the total $\mathrm{P}$ of the $\mathrm{HC}$ prior extraction, were used to compare acid leaching efficiencies. These masses were determined using analytical methods described in Sects. "Standards in Measurements and Testing Protocol" and "Characterization of Solid and Liquid Fractions". To facilitate this comparison, phosphorus release kinetics were estimated using the firstorder rate equation:

$\mathrm{P}_{\text {release }}=\mathrm{P}_{0} \times\left(1-e^{-k t}\right)$

where $\mathrm{P}_{\text {release }}$ is the fraction of phosphorus release at time $t$, $\mathrm{P}_{0}$ is the fraction of phosphorus release at (pseudo-)equilibrium, and $k\left(\mathrm{~h}^{-1}\right)$ is the first order rate constant. Fitting of the dataset where a near complete removal of $\mathrm{P}$ was achieved with the very first minutes of reaction time was made using the smallest best-fitting $k$ values. The quality of the fit was based on the sum-of-squares of the deviation of the model to the experimental data.

\section{Standards in Measurements and Testing Protocol}

$\mathrm{P}$ species in the solid SS and HC phases were identified using the Standards in Measurements and Testing (SMT) extraction protocol $[21,26]$. Briefly, this protocol entails a sequential extraction of phosphorus into five phosphorus fractions: (i) total P (TP); (ii) organic P (OP; phospholipids including DNA and phosphate monoesters); (iii) inorganic $\mathrm{P}$ (IP; including apatite and non-apatite); (iv) non apatite inorganic $\mathrm{P}$ (NAIP) associated with $\mathrm{Al}^{3+}-\mathrm{Fe}^{3+}$ - and $\mathrm{Mn}^{2+}$ (oxy)(hydr)oxides; and (v) apatite P (AP) bonded with $\mathrm{Ca}^{2+}$.

The extraction protocol comprised the following independent steps. TP: a $0.5 \mathrm{~g}$ sample was calcinated for $3 \mathrm{~h}$ 
at $450{ }^{\circ} \mathrm{C}$, and then the ash treated with $20 \mathrm{ml} 3.5 \mathrm{M} \mathrm{HCl}$ with continuous stirring for $16 \mathrm{~h}$. IP: a $0.5 \mathrm{~g}$ sample was mixed with $20 \mathrm{ml} 1 \mathrm{M} \mathrm{HCl}$ with continuous stirring for $16 \mathrm{~h}$. OP: the residue obtained from IP was calcinated for $3 \mathrm{~h}$ at $450{ }^{\circ} \mathrm{C}$, then the ash was mixed with $20 \mathrm{ml} 1 \mathrm{M} \mathrm{HCl}$ under continuous stirring for $16 \mathrm{~h}$. NAIP: a $0.5 \mathrm{~g}$ sample was mixed with $20 \mathrm{ml} \mathrm{NaOH} 1 \mathrm{M}$ for 16 , after which $10 \mathrm{ml}$ of the supernatant was mixed with $4 \mathrm{ml} 3.5 \mathrm{M} \mathrm{HCl}$ and allowed to stand for $16 \mathrm{~h}$ to precipitate any organic matter. AP: residue from the first extraction with $\mathrm{NaOH}$ (NAIP) was extracted again with $20 \mathrm{ml} 1 \mathrm{M} \mathrm{HCl}$ for $16 \mathrm{~h}$. All extraction steps were performed at $20^{\circ} \mathrm{C}$ and centrifuged at $2112 \mathrm{RCF}(2500 \mathrm{rpm}$, Mega Star 1.6R) for $15 \mathrm{~min}$. The extraction experiments (SMT) were performed in triplicate, from which standard deviations were obtained.

Some steps of the SMT protocol were modified as detailed elsewhere [16]. Firstly, a $0.5 \mathrm{~g}$ sample was used instead of $0.2 \mathrm{~g}$, to ensure better reproducibility by using a larger sample mass. Secondly, $\mathrm{PO}_{4}-\mathrm{P}$ was measured using the phosphomolybdenum blue method instead of the vanadomolybdophosphate method. Lastly, a filtration step with activated carbon was removed.

\section{Characterization of Solid and Liquid Fractions}

The ash content of the SS and HC was analyzed in triplicate according to UNE-EN 18122:2016 [EN 18122:2016]. The $\mathrm{pH}$ of the materials was measured in triplicate using an Orion Star A215 pH/conductivity meter. Solid fractions of $0.5 \mathrm{~g}$ were initially shaken in $10 \mathrm{ml}$ deionized water for $1.5 \mathrm{~h}$, as described by Rajkovich [27]. The ash content and HC yield were calculated by Eq. (2) and Eq. (3), respectively:

Ash $=\left(\frac{\text { Mass after heating }}{\text { Initial mass }}\right) \times 100 \%$

Yield $=\left(\frac{\text { Dry mass of } \mathrm{HC}}{\text { Dry mass SS }}\right) \times 100 \%$

Total $\mathrm{P}$ concentrations in the process water, leachate and SMT extracts were analyzed using the phosphomolybdenum blue method according to DIN EN ISO 6878:2004-09 and using the cuvette test (LCK350, Hach-Lange). All extracts were diluted up to $200 \times$ with milliQ water prior to analysis, to match the range of the test kit.

The metal element concentration of the leachate $(\mathrm{Ca}, \mathrm{Mg}$, $\mathrm{Fe}, \mathrm{P}$ and $\mathrm{Al}$ ) was determined in dilute $\mathrm{HNO}_{3}$ by inductively coupled plasma optimal emission spectroscopy, and an Optima 200 DV (PerkinElmer, Überlingen, Germany), equipped with cross-flow nebulizer and double spray chamber, was used for elemental analysis. All analyses were performed in triplicate.
Wavelength dispersive X-ray fluorescence (WD-XRF) was used to determine the main components in solid samples using a Bruker S8-Tiger WD-XRF analyzer equipped with a Rh-anticathode. Detailed information about the method can be found elsewhere [28]. All analyses were performed in triplicate.

Sample imaging of digested SS, HC and HC post-leaching was performed with a scanning electron microscope (SEM, Carl Zeiss Evo) operating in a low vacuum with variable pressure $60 \mathrm{~Pa}$, combined with energy dispersive X-ray spectroscopy (EDS, Oxford instruments X-Mx $80 \mathrm{~mm}^{2}$ ).

\section{Results and Discussion}

\section{Phosphorus Distribution During HTC Processing}

The hydrochar yield recovered after HTC reactions (Table 1) decreased from $67.1 \%$ at $180{ }^{\circ} \mathrm{C}$ to $59.5 \%$ at $250{ }^{\circ} \mathrm{C}$, while the ash content increased with reaction severity. The increase in ash content was the result from losses in volatile matter, and from the dissolution of organic matter into the process water [7], which also correlated with the enrichment of $\mathrm{P}$ and other inorganic matter in the HC (Table 2). Imaging (Fig. 1) showed that HTC transformed the clustered aggregates of SS (Fig. 1a) to fragmentation and a more porous $\mathrm{HC}$ particles, a likely consequently of the decomposition of organic matter (Fig. 1b-d) [29].

The distribution of $\mathrm{P}$ in the $\mathrm{HC}$ and $\mathrm{PW}$ after HTC (Fig. 2) revealed that most of the $\mathrm{P}$ remained in the $\mathrm{HC}$, with a total $\mathrm{P}$ recovery of $75.8 \%$ at $180{ }^{\circ} \mathrm{C}$ and $83.7 \%$ at $250{ }^{\circ} \mathrm{C}$. Similar P recoveries for these temperatures were obtained by Shi et al. [21] with $\sim 85 \%$ recovery at $260{ }^{\circ} \mathrm{C}$ in the HTC treatment of dewatered sewage sludge with an initial $\mathrm{P}$ concentration of $25.4 \mathrm{mg} / \mathrm{g}$. The HTC reaction process also enriched some elements in the $\mathrm{HC}$ with temperature, just as in Shi et al.[21]. In particular, larger HTC temperatures resulted in higher metal concentrations in the HC (Table 2). Those forming Metal-P precipitates especially contributed to $\mathrm{P}$ increments in the $\mathrm{HC}$.

The phase migration and distribution of elements in the solid and liquid fractions were strongly influenced

Table 1 Characteristics of sewage sludge (SS), hydrochar (HC) and process water $(\mathrm{PW})$ resulting from different hydrothermal temperatures $\left(180{ }^{\circ} \mathrm{C}, 215{ }^{\circ} \mathrm{C}\right.$ and $250{ }^{\circ} \mathrm{C}$ ) (average values of three analyses expressed as mean \pm standard deviation)

\begin{tabular}{llllll}
\hline & Ash, $\%$ & Yield, $\%$ & $\mathrm{pH}$ & $\mathrm{pH}$ \\
\hline SS & $43.1 \pm 0.76$ & & $6.15 \pm 0.01$ & \\
HC-180 & $56.4 \pm 0.43$ & $67.1 \pm 0.7$ & $6.21 \pm 0.01$ & PW-180 & $7.06 \pm 0.31$ \\
HC-215 & $63.6 \pm 1.44$ & $65.3 \pm 0.7$ & $6.22 \pm 0.02$ & PW-215 & $7.24 \pm 0.20$ \\
HC-250 & $66.1 \pm 0.60$ & $59.5 \pm 1.3$ & $6.50 \pm 0.01$ & PW-250 & $7.47 \pm 0.18$ \\
\hline
\end{tabular}


Table 2 Main element content in sewage sludge (SS), hydrochar ( $\mathrm{HC}$ ) and $\mathrm{HC}$ residues after acid leaching with either $\mathrm{H}_{2} \mathrm{SO}_{4}$ or $\mathrm{HCl}_{\text {at different }}$ concentrations and temperatures (mean \pm standard deviation, expressed as $\mathrm{mg} / \mathrm{g}$ )

\begin{tabular}{|c|c|c|c|c|c|c|c|c|c|c|}
\hline & $\mathrm{Na}$ & $\mathrm{Mg}$ & $\mathrm{Al}$ & $\mathrm{Si}$ & $\mathrm{P}$ & $\mathrm{K}$ & $\mathrm{Ca}$ & $\mathrm{Fe}$ & $\mathrm{Cl}$ & $S$ \\
\hline SS & $4.4 \pm 0.5$ & $2.2 \pm 0.08$ & $11 \pm 0.16$ & $21 \pm 0.45$ & $45 \pm 1.7$ & $2.4 \pm 0.05$ & $30 \pm 0.90$ & $165 \pm 2.72$ & $0.24 \pm 0.02$ & $15.3 \pm 0.14$ \\
\hline $\mathrm{SS}-\mathrm{H}_{2} \mathrm{SO}_{4}$ & $2.4 \pm 0.07$ & $0.12 \pm 0.24$ & $5.4 \pm 0.36$ & $44 \pm 3.1$ & $3.2 \pm 0.38$ & $2.4 \pm 0.095$ & $7.9 \pm 1.5$ & $5.82 \pm 0.80$ & $0.19 \pm 0.01$ & $37.1 \pm 4.20$ \\
\hline $\mathrm{SS}-\mathrm{HCl}$ & $2.2 \pm 0.07$ & $0.41 \pm 0.06$ & $5.7 \pm 0.21$ & $44 \pm 3.1$ & $4.7 \pm 0.3$ & $2.6 \pm 0.18$ & $1.6 \pm 0.04$ & $8.96 \pm 0.80$ & $9.61 \pm 0.96$ & $21.2 \pm 3.43$ \\
\hline HC-180 & $5.1 \pm 0.5$ & $2.6 \pm 0.33$ & $18 \pm 0.97$ & $31 \pm 6.9$ & $51 \pm 2.1$ & $2.5 \pm 0.36$ & $40 \pm 1.2$ & $201 \pm 4.02$ & $0.03 \pm 0.02$ & $16.9 \pm 0.88$ \\
\hline $\mathrm{HC}-180-\mathrm{H}_{2} \mathrm{SO}_{4}$ & $3.5 \pm 0.5$ & $0.40 \pm 0.17$ & $9.8 \pm 0.54$ & $70 \pm 2.4$ & $0.49 \pm 0.3$ & $3.8 \pm 0.23$ & $8.6 \pm 7.3$ & $7.83 \pm 1.54$ & $0.21 \pm 0.09$ & $51.9 \pm 13.6$ \\
\hline $\mathrm{HC}-180-\mathrm{H}_{2} \mathrm{SO}_{4}-0.25^{*}$ & 4.6 & 1.1 & 9.4 & 46 & 29 & 4.2 & 6.5 & 111 & 0.07 & 41.4 \\
\hline $\mathrm{HC}-180-\mathrm{HCl}^{*}$ & 3.6 & 1.2 & 11 & 70 & 0.91 & 4.3 & 2.9 & 9.91 & 14.4 & 32.0 \\
\hline HC-215 & $4.7 \pm 0.02$ & $2.7 \pm 0.26$ & $18 \pm 1.6$ & $26 \pm 4.9$ & $52 \pm 2.7$ & $2.2 \pm 0.25$ & $39 \pm 1.2$ & $215 \pm 6.78$ & $0.03 \pm 0.02$ & $18.6 \pm 0.22$ \\
\hline $\mathrm{HC}-215-\mathrm{H}_{2} \mathrm{SO}_{4} *$ & 3.4 & 0.4 & 10 & 74 & 0.45 & 4.4 & 10 & 16.8 & 0.10 & 61.5 \\
\hline $\mathrm{HC}-215-\mathrm{HCl}^{*}$ & 4.3 & 1.2 & 12 & 76 & 0.65 & 4.6 & 3.0 & 15.6 & 14 & 41.1 \\
\hline $\mathrm{HC}-250$ & $5.5 \pm 0.2$ & $3.9 \pm 0.16$ & $24 \pm 0.36$ & $39 \pm 0.7$ & $64 \pm 0.72$ & $2.9 \pm 0.051$ & $46 \pm 0.27$ & $258 \pm 1.04$ & $0.02 \pm 0.04$ & $20.2 \pm 0.19$ \\
\hline $\mathrm{HC}-250-\mathrm{H}_{2} \mathrm{SO}_{4} *$ & 3.6 & - & 8.9 & 69 & 1.1 & 3.6 & 31 & 35.9 & 0.21 & 111 \\
\hline $\mathrm{HC}-250-\mathrm{HCl}^{*}$ & 4.3 & 0.81 & 13 & 91 & 1.3 & 5.0 & 3.2 & 31.0 & 25.6 & 52.0 \\
\hline
\end{tabular}

*Values shown are unique measurements

Fig. 1 SEM images of sewage sludge (SS) (a), hydrochar (HC) at $180{ }^{\circ} \mathrm{C}(\mathbf{b}), 215^{\circ} \mathrm{C}(\mathbf{c})$ and $250{ }^{\circ} \mathrm{C}(\mathbf{d})$ and acid-treated $\mathrm{HC}$ after 3 days of acid leaching of $\mathrm{HC}-180$ with $2.5 \mathrm{M} \mathrm{H}_{2} \mathrm{SO}_{4}$ (e) and $2.5 \mathrm{M} \mathrm{HCl}(\mathbf{f}) .600 \times$ magnification
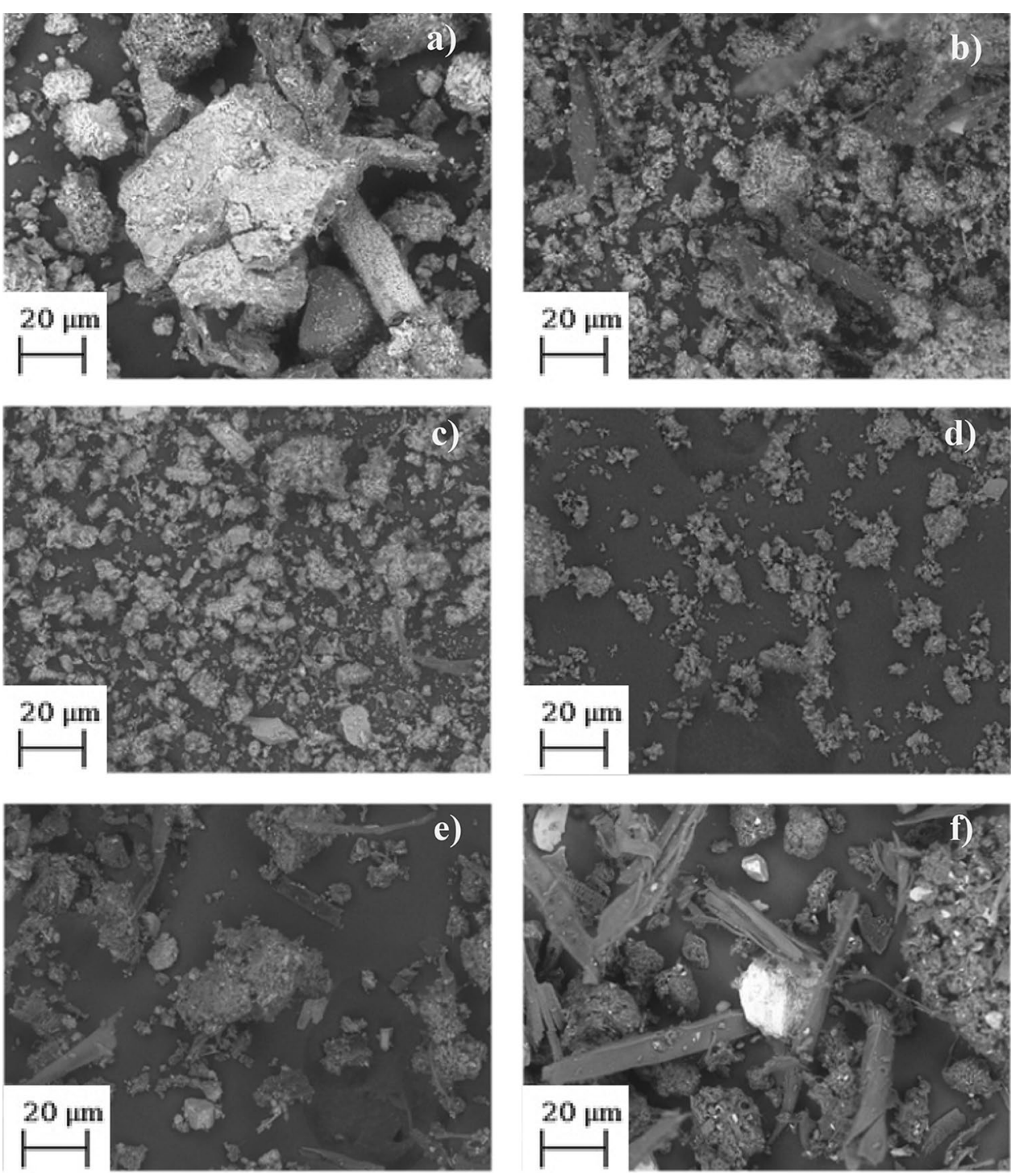


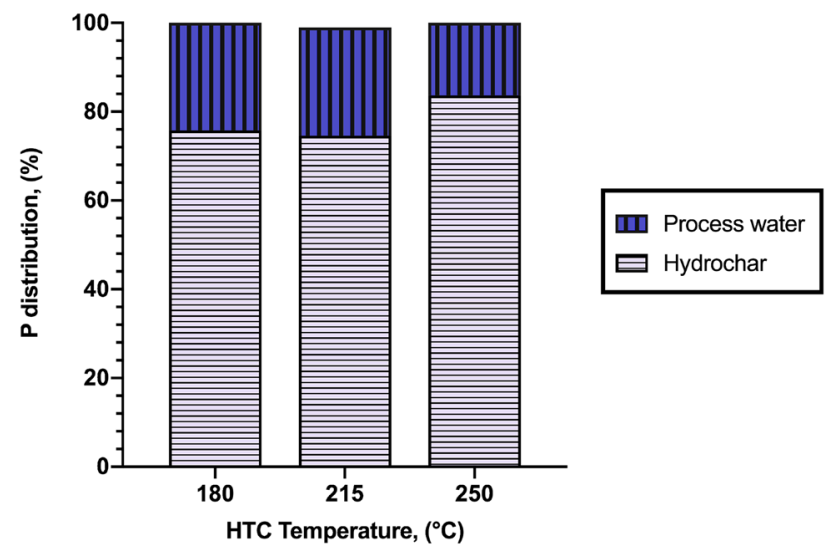

Fig. 2 Phosphorus distribution in hydrochar and process water after hydrothermal carbonization (HTC) at temperatures 180, 215 and $250{ }^{\circ} \mathrm{C}$

by treatment conditions (temperature, reaction time and solution media) and feedstock composition $[23,30]$. The feedstock metal content, such as the high content in sewage sludge, affects the retention of $\mathrm{P}$ in the solid fraction [30]. Iron, aluminum and calcium were the major metals

a)

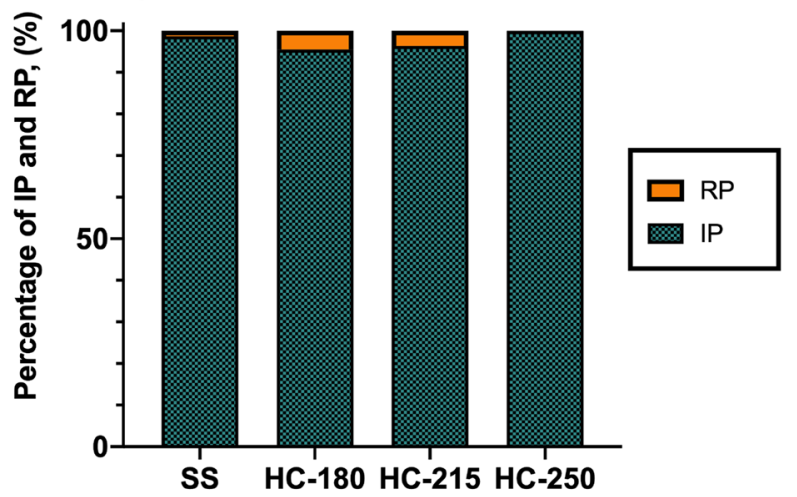

c)

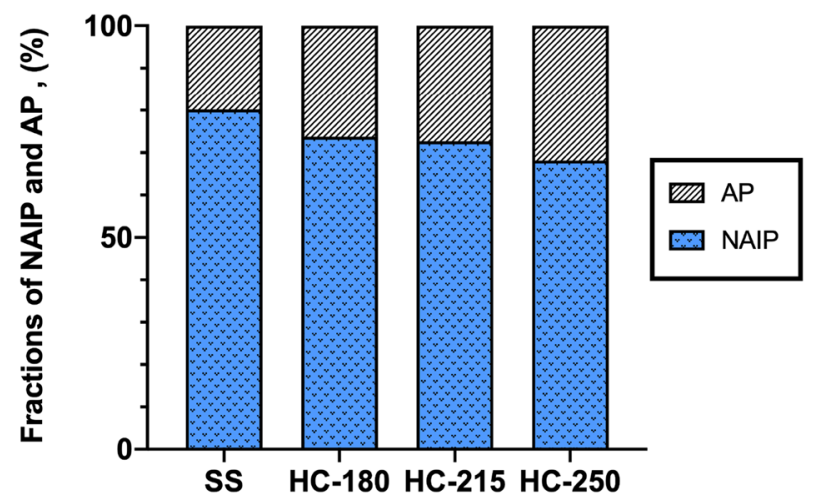

Fig. 3 Phosphorus (P) speciation in sewage sludge (SS) and hydrochar (HC) samples after hydrothermal carbonization (HTC) at different temperatures $\left(180{ }^{\circ} \mathrm{C}, 215^{\circ} \mathrm{C}\right.$ and $\left.250{ }^{\circ} \mathrm{C}\right)$. Average values are found in the SS, with even larger accumulation in the $\mathrm{HCs}$ (Table 2). Because these metals form metal phosphates of low solubility, $\mathrm{P}$ immobilization at higher temperatures was also promoted. In particular, the double addition of $\mathrm{FeCl}_{3}$ as a coagulant in the WWTP, is responsible for the high iron concentrations in both the initial SS and the HC $(165 \mathrm{mg} / \mathrm{g}$ in SS and $258 \mathrm{mg} / \mathrm{g}$ in HC-250). Therefore, based on the iron and phosphorus levels in solution, we expect $\mathrm{FePO}_{4}$ to be the dominant insoluble precipitate. As such, HTC cannot be used by itself to recover phosphorus from sludges with a high metal content: a subsequent post-treatment is required. We will therefore investigate the possibility to release $\mathrm{P}$ using an acid leaching procedure but we first begin with a discussion on P speciation assessed by the SMT protocol.

\section{Phosphorus Speciation by SMT}

$\mathrm{P}$ speciation based on the SMT protocol was used to determine the association of $\mathrm{P}$ with other elements. As shown in Fig. 3b, the TP content was greater in HC samples generated at higher temperatures. TP concentrations increased from $40.2 \mathrm{mg} / \mathrm{g}$ in SS to $56.3 \mathrm{mg} / \mathrm{g}$ in HC-180 and $60.1 \mathrm{mg} / \mathrm{g}$ in HC-215 but did not increase further in HC-250 $(61.0 \mathrm{mg} / \mathrm{g}$

\section{b)}

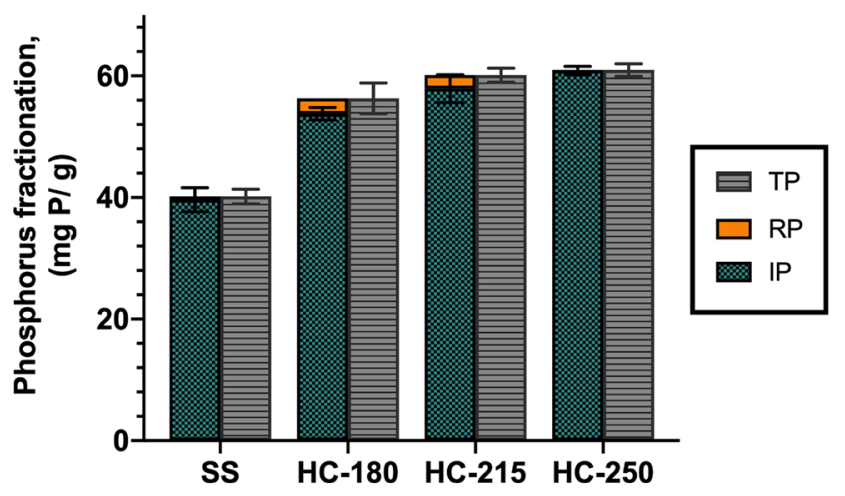

d)

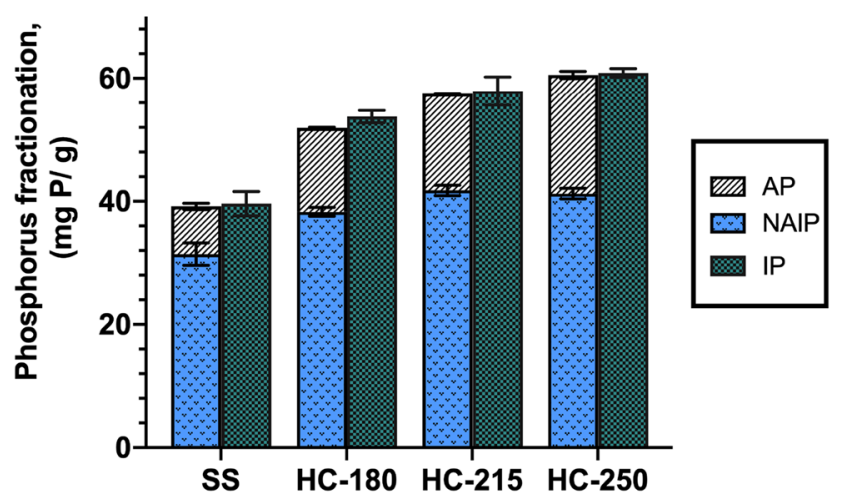

from three experiments, and error bars represent the resulting standard deviation. Total P (TP), Inorganic P (IP), Apatite P (AP) and Non-apatite inorganic P (NAIP) 
TP). IP was the major fraction of TP, both in the initial SS and the HC. The IP content was greater after higher HTC temperatures, with $39.6 \mathrm{mg} / \mathrm{g}$ in the SS but $60.9 \mathrm{mg} / \mathrm{g}$ in HC-250, where it represented more than $95 \%$ of the TP (Fig. 3a).

Because the OP fractions were below the limit of detection, IP values shown in Fig. 3a were subtracted from TP values. These values (rest of $\mathrm{P}, \mathrm{RP}$ ) cannot necessarily be attributed to OP. Anaerobically digested polyphosphate can be released from bacterial cells and hydrolyzed to orthophosphate [31]. We therefore expect that orthophosphate will be the major P entity that associates to metal in SS that has been subjected to anaerobic digestion, and mechanical and thermal processes [31]. Another suggestion is that the high ash content in the initial SS and $\mathrm{HC}$, and the organic content during the inorganic P step in the SMT method, were hydrolyzed further. This could have dissolved and transformed organic phosphates into inorganic phosphate compounds. This phenomenon does occur during HTC, when polyphosphates and organic phosphates are released and precipitated or adsorbed with dissolved metals to form other inorganic phosphate compounds [23,31]. Additionally multivalent metal ions (e.g. $\mathrm{Al}^{3+}, \mathrm{Fe}^{3+}, \mathrm{Ca}^{2+}$ and $\mathrm{Mg}^{2+}$ ) present in the SS tend to form metal phosphates of low solubility, which lowers the potential of P immobilization in the solid fraction [32]. This was verified by the increase in ash and metal content in the HC (Tables 1 and 2).

Figure $3 \mathrm{c}$ shows that NAIP was the main source of IP in the $\mathrm{HC}$ and, in particular, the SS $(80.2 \%)$. However, the proportion of NAIP in the inorganic fraction decreased slightly from $73.8 \%$ at $180{ }^{\circ} \mathrm{C}$ to $68.2 \%$ at $250{ }^{\circ} \mathrm{C}$. Correspondingly, the AP content of $19.8 \%$ in the SS increased to $31.8 \%$ in HC-250. Similar results have been reported by Shi et al. [21], indicating that the NAIP content in both SS and HC is unstable and highly dependent on HTC temperature and $\mathrm{pH}$, ranging from 6.0 at $170{ }^{\circ} \mathrm{C}$ to 8.0 at $320{ }^{\circ} \mathrm{C}$. Another study by Shi et al. [33] of waste activated sludge showed that increasing $\mathrm{pH}$ during HTC promoted the conversion of NAIP to AP under alkaline conditions. However, the $\mathrm{pH}$ of the hydrothermal products in this study slightly increased (Table 1), concentrations of both NAIP and AP gradually increased with increasing HTC reaction temperatures (Fig. 3d). For example, the NAIP concentration increased from $38.3 \mathrm{mg} / \mathrm{g}$ at $180{ }^{\circ} \mathrm{C}$ to $41.3 \mathrm{mg} / \mathrm{g}$ at $250{ }^{\circ} \mathrm{C}$. AP concentrations showed a similar trend, with values of $13.6 \mathrm{mg} / \mathrm{g}$ at $180{ }^{\circ} \mathrm{C}$ increasing to $19.3 \mathrm{mg} / \mathrm{g}$ at $250{ }^{\circ} \mathrm{C}$. Both NAIP and AP constitute the largest fraction of IP present in the original sludge and in HC. These are associated with an increase in precipitated metal ions in the $\mathrm{HC}$, with $\mathrm{Fe}^{3+}, \mathrm{Al}^{3+}$ and $\mathrm{Ca}^{2+}$ contributing to the major metal phosphate compounds. The results for TP in the SS and HC using the SMT method correlated with XRF results (Table 2), providing further support for the interpretations made.

\section{Leaching by Strong Acids}

The ability of solutions of $\mathrm{H}_{2} \mathrm{SO}_{4}$ and $\mathrm{HCl}$ to leach $\mathrm{P}$ from $\mathrm{SS}$ and $\mathrm{HC}$ was studied by tracking the time-resolved $\mathrm{P}$ (Section "P Leaching by Strong Acids") alongside mineralbuilding (Section "Impact of Acid Leaching of MineralBuilding Metals") and heavy metals (Section "Impact of Acid Leaching on Fate of Heavy Metals"). Although acid leaching only slightly modified the morphology of HC-180 (Fig. 1e, f), acid-treated $\mathrm{HC}$ residues ( $\mathrm{HC}-180-\mathrm{H}_{2} \mathrm{SO}_{4}$ and $\mathrm{HC}-180-\mathrm{HCl}$ ) retained the same rough structure and cracked fragmentation as the untreated HC-180. The most discernible difference was the removal of the inorganic content, which had been leached out. These will be discussed in the following sections.

\section{P Leaching by Strong Acids}

P leaching was rapid when exposed to both media, often reaching (pseudo)equilibrium well within the first $\sim 2 \mathrm{~h}$ of reaction time (Fig. 4a-d). P was fully recovered in the three $\mathrm{HC}$, while $\sim 20 \%$ remained associated to SS even after $3 \mathrm{~h}$ of reaction time. Release rates of HC-215 and HC-250 are however substantially slower than in SS and HC-180. This can be appreciated by the first-order rate constants in Fig. 5, extracted from the first $\sim 2 \mathrm{~h}$ of reaction time (Fig. 4). This consequently suggests that HC-215 and HC-250 contain more resilient forms of $\mathrm{P}$ than in HC-180, requiring longer reaction times. Most importantly for this work, our results suggests that HC-180 provides the most complete and timeefficient extraction of $P$.

Our leaching experiments generally revealed more efficient leaching in $\mathrm{H}_{2} \mathrm{SO}_{4}$ than in $\mathrm{HCl}$, likely a result of the double concentration of $\mathrm{H}^{+}$ions [34]. Notable exceptions however include $\mathrm{HC}-180\left(95.5-100 \%\right.$ in $\mathrm{H}_{2} \mathrm{SO}_{4}$ but 91.8-98.6\% in $\mathrm{HCl}$, Fig. 4b1, b2) and SS (e.g., $82 \%$ in $\mathrm{H}_{2} \mathrm{SO}_{4}$ but $85 \%$ in $\mathrm{HCl}$ at $3 \mathrm{~h}$ reaction time, Fig. $4 \mathrm{a} 1$, a2), possibly revealing a role of the counter-anion in the extraction rate and efficiency. However, decreased acid concentration to $0.25 \mathrm{M} \mathrm{H}_{2} \mathrm{SO}_{4}$ only partially recover $\mathrm{P}$ (e.g., $73 \%$ release in $1 \mathrm{~h}$, and $84 \%$ at $3 \mathrm{~h}$, Fig. $4 \mathrm{~b} 3$ ). It may nonetheless be possible that even longer contact times could still provide satisfactory $\mathrm{P}$ release, which is in accordance with acid leaching of incinerated sewage sludge ash (ISSA) and mineral acids [35].

From these leaching experiments, we conclude that HTC facilitates both the handling and extraction of phosphorus in comparison to SS. In particular, HC-180 is not only recommended for its improved sanitary and dewaterability attributes but also for its complete and rapid $\mathrm{P}$ recovering efficiencies, especially in $2.5 \mathrm{M} \mathrm{H}_{2} \mathrm{SO}_{4}$. 
a1)

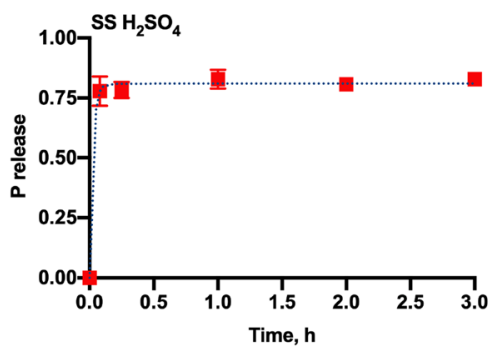

b2)

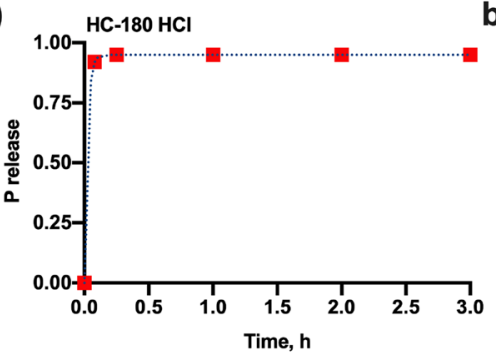

c2)

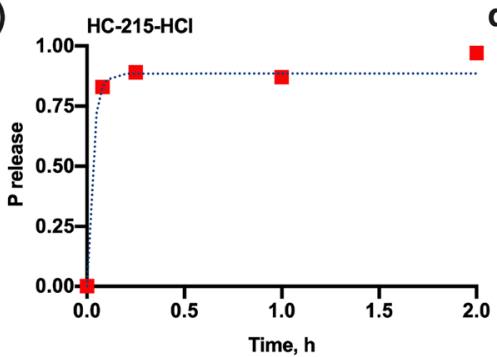

a2)

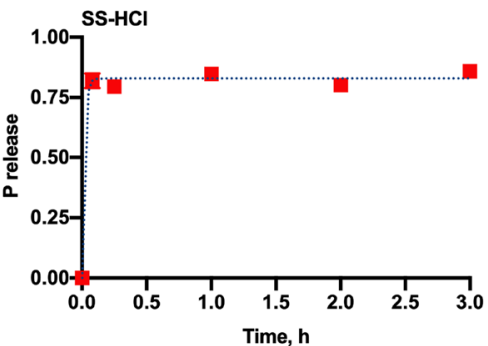

b3)

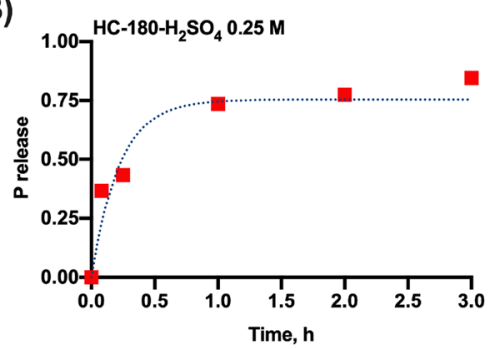

b1)

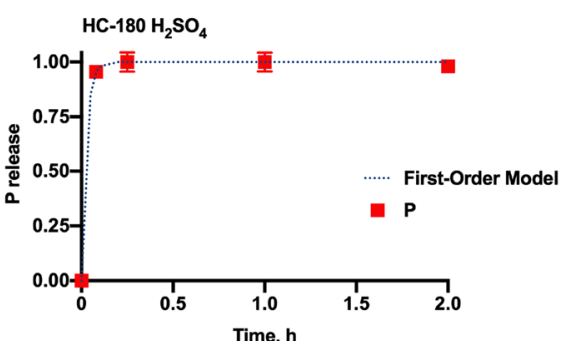

c1)
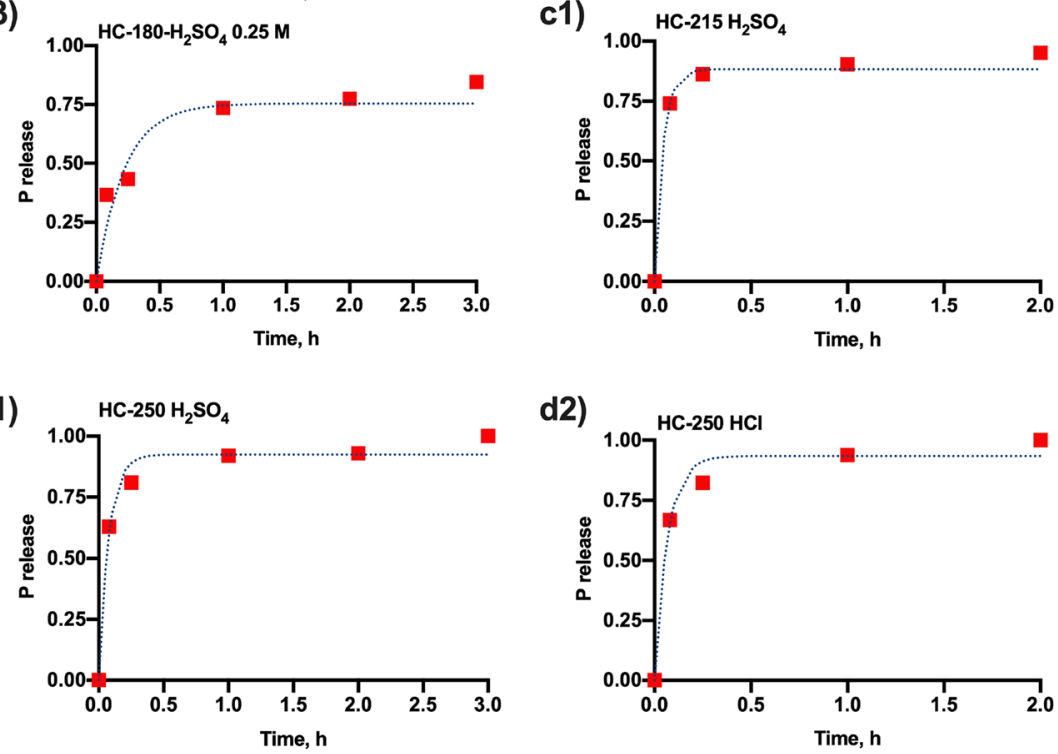

d2)

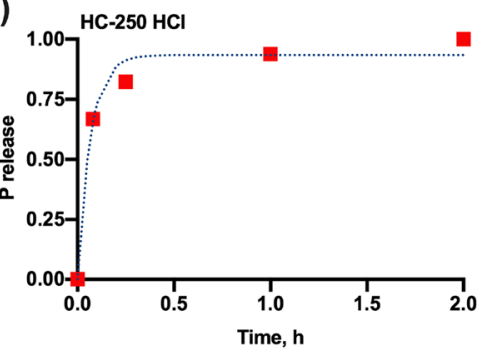

Fig. 4 Phosphorus (P) release kinetics from sewage sludge (SS) (a1-2) and hydrochar (HC) after acid leaching with $\mathrm{H}_{2} \mathrm{SO}_{4}(2.5 \mathrm{M})$ or $\mathrm{HCl}(2.5 \mathrm{M})$ at $180{ }^{\circ} \mathrm{C}(\mathbf{b} 1-2), 215{ }^{\circ} \mathrm{C}(\mathbf{c} 1-2)$ and $250{ }^{\circ} \mathrm{C}(\mathbf{d} 1-2)$. Average values were obtained from three experiments $\left(\mathrm{SS}-\mathrm{H}_{2} \mathrm{SO}_{4}\right.$,
SS- $\mathrm{HCl}$ and $\mathrm{HC}-180-\mathrm{H}_{2} \mathrm{SO}_{4}$ ) and error bars represent standard deviation. Unique measured values presented for the rest of the samples. Note that leachates were extracted with $2.5 \mathrm{M}$ acid with the exception of $\mathrm{HC}-180$ (b3) where $0.25 \mathrm{M} \mathrm{H}_{2} \mathrm{SO}_{4}$ was also used
Fig. 5 First-order kinetic rate constants obtain from fitting time-dependent P-release data of Fig. 4 for sewage sludge (SS) and hydrochars (HC). Rate constants are shown for leaching in $0.25 \mathrm{M}$ (HC-180 only) and $2.5 \mathrm{M} \mathrm{H}_{2} \mathrm{SO}_{4}(\mathbf{a})$ and 2.5 $\mathrm{HCl}$ (b)

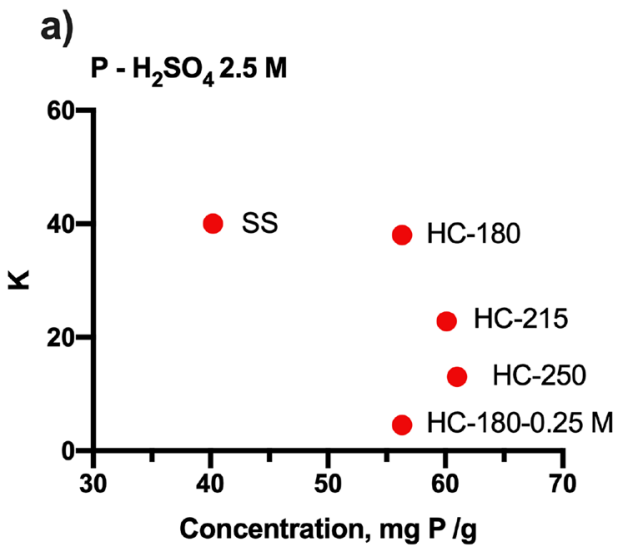

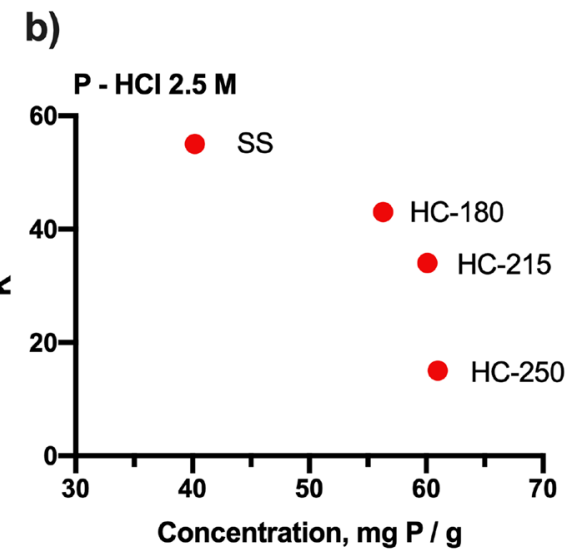

\section{Impact of Acid Leaching of Mineral-Building Metals}

Metals in the solid and leachate were measured before and after $72 \mathrm{~h}$ of acid leaching (Table 2 for solid residues, Fig. 6 for leachates). These measurements (Table 2) revealed a greater enrichment in metal content at the higher 
a)

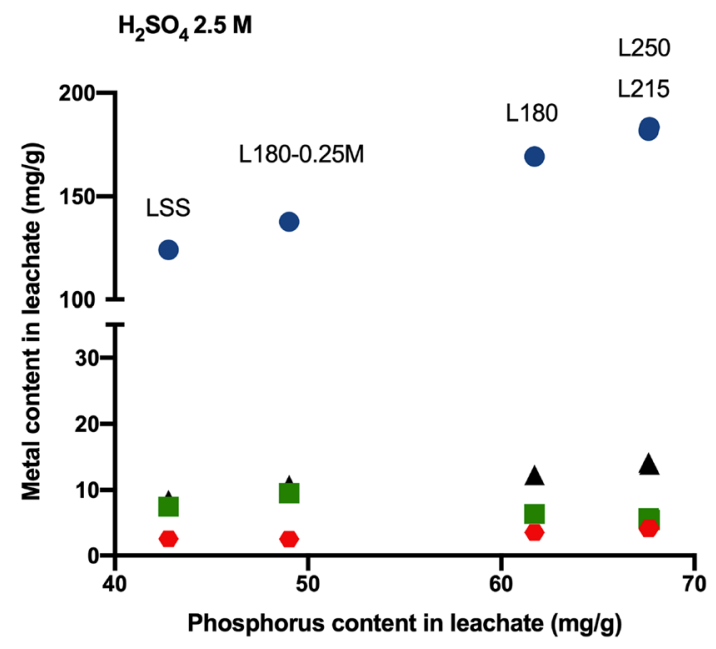

Fig. 6 Metal ( $\mathrm{Mg}, \mathrm{Ca}, \mathrm{Al}$ and $\mathrm{Fe}$ ) content as a function of phosphorus $(\mathrm{P})$ in sewage sludge (SS) and hydrochar (HC) leachates (L) after 3 days of acid leaching with $\mathrm{H}_{2} \mathrm{SO}_{4}$ (a) and $\mathrm{HCl}(\mathbf{b})$ at 180, 215 and

temperatures for HTC treatment. This can be explained by the release of water containing organic matter during HTC reactions, thereby increasing the inorganic content in the solid fraction [21]. The corresponding $\mathrm{HC}$ residues after acid leaching displayed a decrease in metal concentration, however with the exception of the enrichment of Si and K.

In terms of metal release during leaching, only $\mathrm{Ca}, \mathrm{Mg}$, $\mathrm{Al}$ and $\mathrm{Fe}$ were analyzed because of their high concentrations and affinity with $\mathrm{P}$ to form insoluble phosphate precipitates. Solubilization of these multivalent metal cations was affected by acid strength [36] and amount added [37], and is demonstrated in Fig. 6a by showing the relationship between released metal and $\mathrm{P}$. The main reactions for $\mathrm{P}$ release and these metals include [37]:

$\mathrm{Fe}_{3}\left(\mathrm{PO}_{4}\right)_{2}+6 \mathrm{H}^{+} \rightarrow 3 \mathrm{Fe}^{2+}+2 \mathrm{H}_{3} \mathrm{PO}_{4}$

$\mathrm{FePO}_{4}+3 \mathrm{H}^{+} \rightarrow \mathrm{Fe}^{3+}+\mathrm{H}_{3} \mathrm{PO}_{4}$

$\mathrm{AlPO}_{4}+3 \mathrm{H}^{+} \rightarrow \mathrm{Al}^{3+}+\mathrm{H}_{3} \mathrm{PO}_{4}$

$\mathrm{Ca}_{9}(\mathrm{Al})\left(\mathrm{PO}_{4}\right)_{7}+21 \mathrm{H}^{+} \rightarrow 9 \mathrm{Ca}^{2+}+\mathrm{Al}^{3+}+7 \mathrm{H}_{3} \mathrm{PO}_{4}$

These reactions are strongly favored in acid conditions, yet they likely required even greater acid concentrations that initially expected as other acid-soluble compounds (e.g. including $\mathrm{CaO}, \mathrm{CaCO}_{3}$ and $\mathrm{MgO}$ ) might consume a portion of the acid [37, 38].

The release of Fe increased from $121 \mathrm{mg} / \mathrm{g}$ for L-SS$\mathrm{H}_{2} \mathrm{SO}_{4}$ to $180 \mathrm{mg} / \mathrm{g}$ for $\mathrm{L}-250-\mathrm{H}_{2} \mathrm{SO}_{4}$. Lowering acid concentration to $0.25 \mathrm{M}$ acid extracted $138 \mathrm{mg} / \mathrm{g}$ in b)

\section{$\mathrm{HCl} 2.5 \mathrm{M}$}

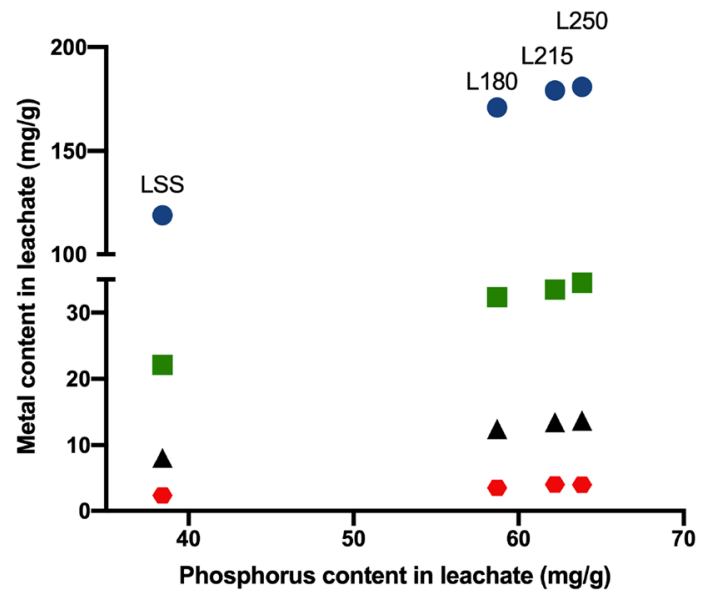

$250{ }^{\circ} \mathrm{C}$. Note that leachates were extracted with $2.5 \mathrm{M}$ acid with the exception of $\mathrm{HC}-180$ (a) where $0.25 \mathrm{M} \mathrm{H}_{2} \mathrm{SO}_{4}$ was also used

L-180- $\mathrm{H}_{2} \mathrm{SO}_{4}$ (Fig. 6a). A similar trend was observed with $\mathrm{HCl}$ leaching (Fig. 6b), where Fe reached a maximum release of $181 \mathrm{mg} / \mathrm{g}$ with $\mathrm{HC}-250$.

Concentrations of $\mathrm{Mg}, \mathrm{Al}$ and Ca released from SS and $\mathrm{HC}$ remained relatively constant, and much lower compared with Fe and $\mathrm{P}$ concentrations (Fig. 6a, b). The most pronounced difference was seen with the leaching of $\mathrm{Ca}$ with $\mathrm{HCl}$. Here, the Ca content increased from $22.0 \mathrm{mg} / \mathrm{g}$ (L-SS$\mathrm{HCl})$ to $34.5 \mathrm{mg} / \mathrm{g}(\mathrm{L}-250-\mathrm{HCl})$, compared with a decrease with $\mathrm{H}_{2} \mathrm{SO}_{4}$ from $7.48 \mathrm{mg} / \mathrm{g}\left(\mathrm{L}-\mathrm{SS}-\mathrm{H}_{2} \mathrm{SO}_{4}\right)$ to $5.58 \mathrm{mg} / \mathrm{g}$ (L-250- $\mathrm{H}_{2} \mathrm{SO}_{4}$ ) with $\mathrm{H}_{2} \mathrm{SO}_{4}$ (Fig. 6b). This might be a result of Ca-sulphate precipitation that remained in the $\mathrm{HC}$-residue after extraction, resulting in a lower Ca release compared to a higher release with $\mathrm{HCl}$ (Table 2).

Acid leaching also promotes metal dissolution, especially iron (Fig. 6 and Table 2) where Fe/P ratios increased from LSS to L250. This consequently implies that $\mathrm{P}$ recovery from products other than iron associated to phosphorus is challenging. It also implies that HCs of lower P solubility are not ideal materials for producing fertilizers [39]. For this reason, phosphate is commonly recovered as calcium phosphate $\left(\mathrm{Ca}_{3}\left(\mathrm{PO}_{4}\right)_{2}\right)$ or struvite $\left(\mathrm{NH}_{4} \mathrm{MgPO}_{4} \bullet 6 \mathrm{H}_{2} \mathrm{O}\right)$, both of which are common fertilizers [40]. From the leaching results in this study, calcium phosphate could be recovered from the high levels of $\mathrm{Ca}$ and $\mathrm{P}$ released during leaching of $\mathrm{HC}$ with $\mathrm{HCl}$ (Fig. 6b). However, due to high levels of $\mathrm{Fe}$ released to the leachate a purification step is required prior precipitation of calcium phosphate or struvite, as already demonstrated by Liang et al. [38] with SS incineration ash. On the other hand, the process water from HTC could provide a source of ammonium ions that could then be used to precipitate struvite with the P-rich leachate. For example, by 
mixing the correct ratio of $\mathrm{Mg}^{2+}$, process water rich in $\mathrm{NH}^{4+}$ and phosphate-rich leachate, Becker et al. [12] obtained a phosphate recovery of $\sim 80 \%$.

\section{Impact of Acid Leaching on Fate of Heavy Metals}

HTC of SS and subsequent acid leaching of the HC yields high recovery of $\mathrm{P}$ and most common multivalent cations. However, heavy metal (HM) concentrations are also important to monitor throughout the process since they have a bearing on the potential use of the products as fertilizer. The HM content was measured in both $\mathrm{HC}$ and HC leaching residues after $72 \mathrm{~h}$ (Table 3, Fig. 7). Zinc, copper and manganese were detected at the highest amounts, with concentrations ranging from 140 to $620 \mathrm{mg} / \mathrm{kg}$, followed by nickel and vanadium, at concentrations ranging from 33 to $40 \mathrm{mg}$ / $\mathrm{kg}$. The HM concentrations in $\mathrm{HC}$ were all highest with the highest carbonization temperatures, which can be explained by a loss of mass at the higher temperatures, enriching the heavy metals in the solid phase [23, 41].

A similar trend was observed for $\mathrm{P}$, multivalent cations and HMs during acid leaching of HC (Table 3). For Mn and $\mathrm{Zn}$, more than $70 \%$ was released with both acids, apart from slightly less than $60 \%$ of $\mathrm{Zn}$ released by $\mathrm{HC}-250-\mathrm{H}_{2} \mathrm{SO}_{4}$. $\mathrm{Ni}$ release displayed little variation during acid leaching, with more than $90 \%$ remaining in the solid phase after acid treatment. $\mathrm{Cu}$ release showed the biggest variation between the two acids: leaching $\mathrm{HC}$ at $180{ }^{\circ} \mathrm{C}$ with $2.5 \mathrm{M} \mathrm{H}_{2} \mathrm{SO}_{4}$ resulted in a $44.8 \%$ release, while $2.5 \mathrm{M} \mathrm{HCl}$ released 94.9\%. The same trend was seen with HC-215 and HC-250, $\mathrm{HCl}$ releasing higher percentages of $\mathrm{Cu}$ compared with $\mathrm{H}_{2} \mathrm{SO}_{4}$. Fang et al. [34] suggested that leaching with $\mathrm{H}_{2} \mathrm{SO}_{4}$ resulted in the precipitation of some metal-sulphate which would decrease the metal concentration in the leachate. As such, the remaining sulphur and chlorine compounds in HC-residues (Tables 2, 3), could possibly be explained by coexisting $\mathrm{CuSO}_{4}$ precipitate and copper-chloride aqueous complexes. Overall, acid leaching at higher concentrations facilitated heavy metal release, and especially for $\mathrm{Zn}, \mathrm{Cu}$ and Mn. This aligns with work by Fang et al. [42] where a single $\mathrm{P}$ extraction step from ISSA using $0.2 \mathrm{M} \mathrm{H}_{2} \mathrm{SO}_{4}$ predominantly released $\mathrm{Cu}, \mathrm{Mn}$ and $\mathrm{Zn}$ compared to other trace metals (e.g. As, $\mathrm{Pb}$, Ni and $\mathrm{Cr}$ ).

$\mathrm{P}$ extraction seemed to be more convenient with $\mathrm{H}_{2} \mathrm{SO}_{4}$ as a result of efficient $\mathrm{P}$ release and $\mathrm{Cu}$ release. The percentage of heavy metals transferred to the leachate remained relatively high for the other elements, indicating the need for a pre- or post-treatment (e.g., by EDTA to achieve adequate purification). Fang et al. [34] suggested that pretreatment of ISSA with EDTA could remove heavy metals prior to acid leaching. However, it should be noted that the levels of heavy metals detected in this study were still well below the levels of impurities found in phosphate rock and commercial inorganic fertilizer such as TSP (triple super phosphate) [43]. Additionally, levels of $\mathrm{Ni}, \mathrm{Cr}$ and $\mathrm{Cd}$ were even orders of magnitude higher in TSP compared to levels measured in this study [43].

\section{Conclusions}

HTC of SS at 180,215 , and $250^{\circ} \mathrm{C}$ ) revealed that $\mathrm{P}$ remained relatively immobilized ( $>75 \%$ of total $\mathrm{P}$ ) in hydrochars, and that almost all of the phosphorus was present as inorganic P. The high NAIP content of the hydrochars was directly affected by the double addition of $\mathrm{FeCl}_{3}$ in the WWTP.

The higher levels of acid-induced phosphorus released (80-100\%) in HTC than in SS (up to 85\%) showed that HTC
Table 3 Heavy metal content in sewage sludge (SS), hydrochar (HC) and $\mathrm{HC}$ residues after acid leaching with either $\mathrm{H}_{2} \mathrm{SO}_{4}$ or $\mathrm{HCl}$ at different concentrations and temperatures (mean \pm standard deviation, expressed as $\mathrm{mg} / \mathrm{kg}$ )

\begin{tabular}{llllll}
\hline & $\mathrm{V}$ & $\mathrm{Mn}$ & $\mathrm{Ni}$ & $\mathrm{Cu}$ & $\mathrm{Zn}$ \\
\hline $\mathrm{SS}$ & $40.7 \pm 4$ & $415 \pm 9$ & $33.0 \pm 3$ & $143.3 \pm 4$ & $620.0 \pm 6.6$ \\
$\mathrm{SS}-\mathrm{H}_{2} \mathrm{SO}_{4}$ & $9.00 \pm 5$ & $105 \pm 3$ & $13.0 \pm 3$ & - & $21.67 \pm 2.3$ \\
$\mathrm{SS}-\mathrm{HCl}$ & $8.67 \pm 2$ & $111 \pm 2$ & $9.00 \pm 1$ & - & $11.00 \pm 3.5$ \\
$\mathrm{HC}-180$ & $50.0 \pm 5$ & $508 \pm 17$ & $62.0 \pm 4$ & $216.7 \pm 2$ & $844.0 \pm 19$ \\
$\mathrm{HC}-180-\mathrm{H}_{2} \mathrm{SO}_{4}$ & $20.3 \pm 2$ & $123 \pm 6$ & $67.0 \pm 4$ & $119.7 \pm 8$ & $87.33 \pm 18$ \\
$\mathrm{HC}-180-\mathrm{H}_{2} \mathrm{SO}_{4}-0.25 *$ & 35.0 & 156 & 61.0 & 233.0 & 286.0 \\
$\mathrm{HC}-180-\mathrm{HCl}^{*}$ & 19.0 & 126 & 53.0 & 11.00 & 38.00 \\
$\mathrm{HC}-215$ & $52.7 \pm 4$ & $538 \pm 19$ & $72.0 \pm 5$ & $224.3 \pm 8$ & $926.0 \pm 11$ \\
$\mathrm{HC}-215-\mathrm{H}_{2} \mathrm{SO}_{4} *$ & 32.0 & 136 & 70.0 & 229.0 & 185.0 \\
$\mathrm{HC}-215-\mathrm{HCl}^{*}$ & 36.0 & 139 & 70.0 & 36.00 & 53.00 \\
$\mathrm{HC}-250$ & $62.3 \pm 5$ & $632 \pm 14$ & $476 \pm 15$ & $298.7 \pm 9$ & $1089 \pm 10$ \\
$\mathrm{HC}-250-\mathrm{H}_{2} \mathrm{SO}_{4} *$ & 41.0 & 145 & 1677 & 406.0 & 461.0 \\
$\mathrm{HC}-250-\mathrm{HCl}^{*}$ & 54.0 & 158 & 1583 & 77.00 & 168.0 \\
\hline
\end{tabular}

*Values shown are unique measurements 

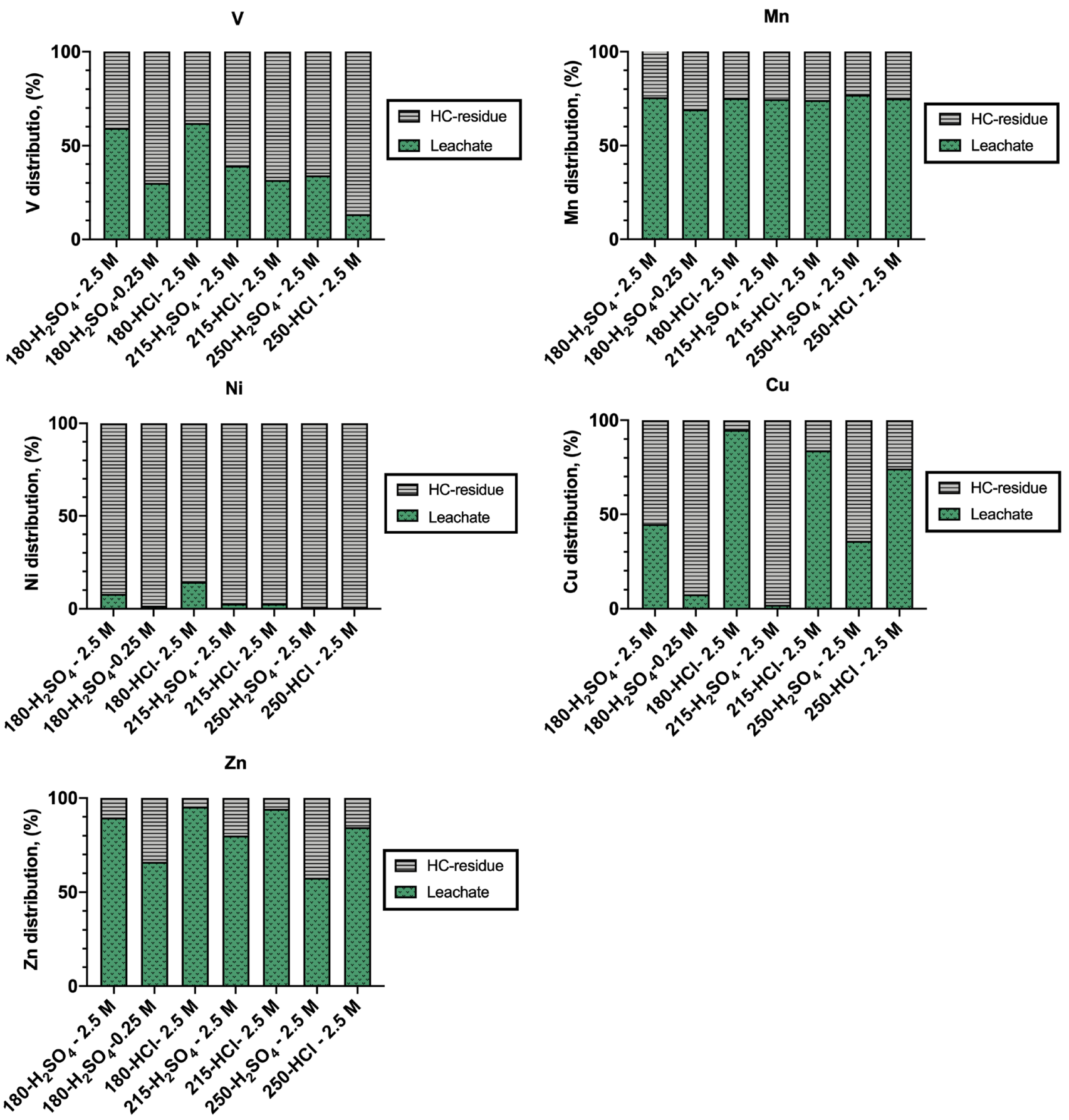

Fig. 7 Heavy metal distribution within hydrochar ( $\mathrm{HC}$ ) residues and leachate after acid leaching with $0.25 \mathrm{M} \mathrm{H}_{2} \mathrm{SO}_{4}$ at $180{ }^{\circ} \mathrm{C}$, or $2.5 \mathrm{M} \mathrm{H}_{2} \mathrm{SO}_{4}$ or $2.5 \mathrm{M} \mathrm{HCl}$ at 180,215 and $250^{\circ} \mathrm{C}$

is a promising route for $\mathrm{P}$ recovery from complex wastes residues. Temperature was shown to be an important factor, as $\mathrm{P}$ was released faster in hydrochars produced at lowest temperature $\left(180^{\circ} \mathrm{C}\right)$ considered in this work. We therefore recommend that future studies on sludge sanitation, dewatering improvement, as well as time- and energy-efficient phosphorus recovery be focused on hydrochars produced at low temperatures.
Leaching with acid resulted in the transfer not only of phosphorus but also of high amounts of iron into the leachate, iron phosphate being as the major precipitate compound expected. Because the plant availability of iron phosphates is limited, a pre- or post-treatment is needed to increase the purity of the $\mathrm{P}$ leachate for fertilizer production. As such, the HTC-acid leaching approach opens up for an alternative process to recover phosphorus from SS. 
Although the composition of the sludge determines its application in agriculture, this new source of phosphorus is closer to become a more sustainable alternative to our current-day dependence on phosphate rocks.

Acknowledgements The authors would like to thank Johan Sandgren and Christina Åström for the sampling of the material, Sven Tunel and Sara Boström for the information provided of the WWTP. We also would like to thank the Industrial Doctoral School for Research and Innovation, Umeå University and Water and Waste competence in the North (VAKIN), for supporting this work. JFB thanks for the Swedish Research Council (2020-04853) for support.

Author Contributions $\mathrm{CP}, \mathrm{JFB}, \mathrm{SJ}, \mathrm{TG}$ and JF conceived and planned the experiments. CP carried out the experiments. CP, JFB, SJ, TG and JF contributed to the interpretation of the results. CP took the lead in writing the manuscript. All authors provided critical feedback and helped shape the research, analysis and manuscript.

Funding Open access funding provided by Umea University. This project was funded by the Industrial Doctoral School, Umeå University, Sweden, and Vatten och Avfallskompetens i Norr AB, Sweden.

Data Availability All data generated and analysed during this study are included in this published article, raw data files such as spectrum, images from SEM, are available from the corresponding author on reasonable request.

\section{Declarations}

Conflicts of Interest The authors declare that there are no conflicts of interest.

Open Access This article is licensed under a Creative Commons Attribution 4.0 International License, which permits use, sharing, adaptation, distribution and reproduction in any medium or format, as long as you give appropriate credit to the original author(s) and the source, provide a link to the Creative Commons licence, and indicate if changes were made. The images or other third party material in this article are included in the article's Creative Commons licence, unless indicated otherwise in a credit line to the material. If material is not included in the article's Creative Commons licence and your intended use is not permitted by statutory regulation or exceeds the permitted use, you will need to obtain permission directly from the copyright holder. To view a copy of this licence, visit http://creativecommons.org/licenses/by/4.0/.

\section{References}

1. Jasinski, S.M.: Minerals yearbook phosphate rock. 1-9 (2016)

2. Gong, Y., Zhao, D.: 3. 11 Physical—chemical processes for phosphorus removal and recovery. Elsevier Ltd, Nether lands (2014)

3. Konieczka, P.: A review of phosphorus recovery methods at various steps of wastewater treatment and sewage sludge management. The concept of "no solid waste generation" and analytical methods. J. Clean. Prod 142, 1728-1740 (2017). https://doi.org/ 10.1016/j.jclepro.2016.11.116

4. Cordell, D., Smit, A.L., Rosemarin, A.: Sustainable use of phosphorus. (2009)

5. Cordell, D., Drangert, J.O., White, S.: The story of phosphorus: Global food security and food for thought. Glob. Environ. Chang.
19, 292-305 (2009). https://doi.org/10.1016/j.gloenvcha.2008.10. 009

6. Blöcher, C., Niewersch, C., Melin, T.: Phosphorus recovery from sewage sludge with a hybrid process of low pressure wet oxidation and nanofiltration. Water Res. 46, 2009-2019 (2012). https://doi. org/10.1016/j.watres.2012.01.022

7. Tasca, A.L., Puccini, M., Gori, R., Corsi, I., Galletti, A.M.R., Vitolo, S.: Hydrothermal carbonization of sewage sludge: A critical analysis of process severity, hydrochar properties and environmental implications. Waste Manag. 93, 1-13 (2019). https://doi. org/10.1016/j.wasman.2019.05.027

8. Wang, L., Chang, Y., Li, A.: Hydrothermal carbonization for energy-efficient processing of sewage sludge: A review. Renew. Sustain. Energy Rev. 108, 423-440 (2019). https://doi.org/10. 1016/j.rser.2019.04.011

9. Chew, J.J., Doshi, V.: Recent advances in biomass pretreatment-Torrefaction fundamentals and technology. Renew. Sustain. Energy Rev. 15, 4212-4222 (2011). https://doi.org/10.1016/j. rser.2011.09.017

10. Kambo, H.S., Dutta, A.: A comparative review of biochar and hydrochar in terms of production, physico-chemical properties and applications. Renew. Sustain. Energy Rev. 45, 359-378 (2015). https://doi.org/10.1016/j.rser.2015.01.050

11. Gao, N., Kamran, K., Quan, C., Williams, P.T.: Thermochemical conversion of sewage sludge: A critical review. Prog. Energy Combust. Sci. 79, 100843 (2020). https://doi.org/10.1016/j.pecs. 2020.100843

12. Becker, G.C., Wüst, D., Köhler, H., Lautenbach, A., Kruse, A.: Novel approach of phosphate-reclamation as struvite from sewage sludge by utilising hydrothermal carbonization. J. Environ. Manage. 238, 119-125 (2019). https://doi.org/10.1016/j.jenvman. 2019.02.121

13. Libra, J.A., Ro, K.S., Kammann, C., Funke, A., Berge, N.D., Neubauer, Y., Titirici, M.M., Fühner, C., Bens, O., Kern, J., Emmerich, K.H.: Hydrothermal carbonization of biomass residuals: A comparative review of the chemistry, processes and applications of wet and dry pyrolysis. Biofuels 2, 71-106 (2011). https://doi. org $/ 10.4155 /$ bfs. 10.81

14. Wang, L., Chang, Y., Liu, Q.: Fate and distribution of nutrients and heavy metals during hydrothermal carbonization of sewage sludge with implication to land application. J. Clean. Prod. 225, 972-983 (2019). https://doi.org/10.1016/j.jclepro.2019.03.347

15. Lin, Y., Ma, X., Peng, X., Hu, S., Yu, Z., Fang, S.: Effect of hydrothermal carbonization temperature on combustion behavior of hydrochar fuel from paper sludge. Appl. Therm. Eng. 91, 574-582 (2015). https://doi.org/10.1016/j.applthermaleng.2015. 08.064

16. Zhao, X., Becker, G.C., Faweya, N., Rodriguez Correa, C., Yang, S., Xie, X., Kruse, A.: Fertilizer and activated carbon production by hydrothermal carbonization of digestate. Biomass Convers. Biorefinery. 8, 423-436 (2018). https://doi.org/10.1007/ s13399-017-0291-5

17. Heilmann, S.M., Jader, L.R., Harned, L.A., Sadowsky, M.J., Schendel, F.J., Lefebvre, P.A., von Keitz, M.G., Valentas, K.J.: Hydrothermal carbonization of microalgae II. Fatty acid, char, and algal nutrient products. Appl. Energy. 88, 3286-3290 (2011). https://doi.org/10.1016/j.apenergy.2010.12.041

18. Heilmann, S.M., Jader, L.R., Sadowsky, M.J., Schendel, F.J., von Keitz, M.G., Valentas, K.J.: Hydrothermal carbonization of distiller's grains. Biomass Bioenerg. 35, 2526-2533 (2011). https:// doi.org/10.1016/j.biombioe.2011.02.022

19. Heilmann, S.M., Molde, J.S., Timler, J.G., Wood, B.M., Mikula, A.L., Vozhdayev, G.V., Colosky, E.C., Spokas, K.A., Valentas, K.J.: Phosphorus reclamation through hydrothermal carbonization of animal manures. Environ. Sci. Technol. 48(17), 10323-10329 (2014). https://doi.org/10.1021/es501872k 
20. Park, T., Ampunan, V., Lee, S., Chung, E.: Chemical behavior of different species of phosphorus in coagulation. Chemosphere 144, 2264-2269 (2016). https://doi.org/10.1016/j.chemosphere.2015. 10.131

21. Shi, Y., Luo, G., Rao, Y., Chen, H., Zhang, S.: Hydrothermal conversion of dewatered sewage sludge: Focusing on the transformation mechanism and recovery of phosphorus. Chemosphere $\mathbf{2 2 8}$, 619-628 (2019). https://doi.org/10.1016/j.chemosphere.2019.04. 109

22. Marin-Batista, J.D., Mohedano, A.F., Rodríguez, J.J., de la Rubia, M.A.: Energy and phosphorous recovery through hydrothermal carbonization of digested sewage sludge. Waste Manag. 105, 566-574 (2020). https://doi.org/10.1016/j.wasman.2020.03.004

23. Wang, H., Yang, Z., Li, X., Liu, Y.: Distribution and transformation behaviors of heavy metals and phosphorus during hydrothermal carbonization of sewage sludge. Environ. Sci. Pollut. Res. 27, 17109-17122 (2020). https://doi.org/10.1007/ s11356-020-08098-4

24. Wang, T., Zhai, Y., Zhu, Y., Peng, C., Wang, T., Xu, B., Li, C., Zeng, G.: Feedwater $\mathrm{pH}$ affects phosphorus transformation during hydrothermal carbonization of sewage sludge. Bioresour. Technol. 245, 182-187 (2017). https://doi.org/10.1016/j.biortech.2017.08. 114

25. Stark, K., Plaza, E., Hultman, B.: Phosphorus release from ash, dried sludge and sludge residue from supercritical water oxidation by acid or base. Chemosphere 62, 827-832 (2006). https://doi.org/ 10.1016/j.chemosphere.2005.04.069

26. Pe, M.Æ.B.: Analytical phosphorus fractionation in sewage sludge and sediment samples. Anal. Bioanal. Chem. 381, 873-878 (2005). https://doi.org/10.1007/s00216-004-2989-z

27. Rajkovich, S., Enders, A., Hanley, K., Hyland, C., Zimmerman, A.R., Lehmann, J.: Corn growth and nitrogen nutrition after additions of biochars with varying properties to a temperate soil. Biol. Fertil. Soils. 48, 271-284 (2012). https://doi.org/10.1007/ s00374-011-0624-7

28. Rydberg, J.: Wavelength dispersive X-ray fluorescence spectroscopy as a fast, non-destructive and cost-effective analytical method for determining the geochemical composition of small loose-powder sediment samples. J. Paleolimnol. 52, 265-276 (2014). https://doi.org/10.1007/s10933-014-9792-4

29. Gai, C., Guo, Y., Liu, T., Peng, N., Liu, Z.: Hydrogen-rich gas production by steam gasification of hydrochar derived from sewage sludge. Int. J. Hydrogen Energy. 41, 3363-3372 (2016). https:// doi.org/10.1016/j.ijhydene.2015.12.188

30. Huang, R., Fang, C., Lu, X., Jiang, R., Tang, Y.: Transformation of Phosphorus during (Hydro)thermal treatments of solid biowastes: reaction mechanisms and implications for $\mathrm{P}$ reclamation and recycling. Environ. Sci. Technol. 51, 10284-10298 (2017). https://doi. org/10.1021/acs.est.7b02011

31. Huang, R., Tang, Y.: Speciation dynamics of phosphorus during (Hydro)thermal treatments of sewage sludge. Environ. Sci. Technol. 49(24), 14466-14474 (2015). https://doi.org/10.1021/acs.est. $5 \mathrm{~b} 04140$

32. Huang, R., Fang, C., Zhang, B., Tang, Y.: Transformations of phosphorus speciation during (Hydro)thermal treatments of animal manures. Environ. Sci. Technol. 52(5), 3016-3026 (2018). https://doi.org/10.1021/acs.est.7b05203

33. Shi, Y., Chen, Z., Cao, Y., Fan, J., Clark, J.H., Luo, G., Zhang, S.: Migration and transformation mechanism of phosphorus in waste activated sludge during anaerobic fermentation and hydrothermal conversion. J. Hazard. Mater. 403, 123649 (2021). https://doi.org/ 10.1016/j.jhazmat.2020.123649

34. Fang, L., Li, J., Zhi, M., Cheeseman, C.R., Tsang, D.C.W., Donatello, S., Sun, C.: Chemosphere Phosphorus recovery and leaching of trace elements from incinerated sewage sludge ash (ISSA). Chemosphere 193, 278-287 (2019). https://doi.org/10.1016/j. chemosphere.2017.11.023

35. Biswas, B.K., Inoue, K., Harada, H., Ohto, K., Kawakita, H.: Leaching of phosphorus from incinerated sewage sludge ash by means of acid extraction followed by adsorption on orange waste gel. J. Environ. Sci. 21, 1753-1760 (2009). https://doi.org/10. 1016/S1001-0742(08)62484-5

36. Dai, L., Yang, B., Li, H., Tan, F., Zhu, N., Zhu, Q., He, M., Ran, Y., Hu, G.: A synergistic combination of nutrient reclamation from manure and resultant hydrochar upgradation by acidsupported hydrothermal carbonization. Bioresour. Technol. 243, 860-866 (2017). https://doi.org/10.1016/j.biortech.2017.07.016

37. Petzet, S., Peplinski, B., Cornel, P.: On wet chemical phosphorus recovery from sewage sludge ash by acidic or alkaline leaching and an optimized combination of both. Water Res. 46, 3769-3780 (2012). https://doi.org/10.1016/j.watres.2012.03.068

38. Liang, S., Chen, H., Zeng, X., Li, Z., Yu, W., Xiao, K., Hu, J., Hou, H., Liu, B., Tao, S., Yang, J.: A comparison between sulfuric acid and oxalic acid leaching with subsequent purification and precipitation for phosphorus recovery from sewage sludge incineration ash. Water Res. 159, 242-251 (2019). https://doi.org/10. 1016/j.watres.2019.05.022

39. Levlin, E., Löwén, M., Stark, K.: Phosphorus recovery from sludge incineration ash and supercritical water oxidation residues with use of acid and base. Water Resour. 19-28 (2007)

40. Chrispim, M.C., Scholz, M., Nolasco, M.A.: Phosphorus recovery from municipal wastewater treatment: Critical review of challenges and opportunities for developing countries. J. Environ. Manage. 248, 109268 (2019). https://doi.org/10.1016/j.jenvman. 2019.109268

41. Mcgaughy, K., Tou, M.: Recovery of Macro and Micro-Nutrients by Hydrothermal Carbonization of Septage. (2018). https://doi. org/10.1021/acs.jafc.7b05667

42. Fang, L., Li, J., Donatello, S., Cheeseman, C.R., Wang, Q., Poon, C.S., Tsang, D.C.W.: Recovery of phosphorus from incinerated sewage sludge ash by combined two-step extraction and selective precipitation. Chem. Eng. J. 348, 74-83 (2018). https://doi.org/ 10.1016/j.cej.2018.04.201

43. Hall, R.L., Boisen Staal, L., Macintosh, K.A., McGrath, J.W., Bailey, J., Black, L., Gro Nielsen, U., Reitzel, K., Williams, P.N.: Phosphorus speciation and fertiliser performance characteristics: A comparison of waste recovered struvites from global sources. Geoderma 362, 114096 (2020). https://doi.org/10.1016/j.geode rma.2019.114096

Publisher's Note Springer Nature remains neutral with regard to jurisdictional claims in published maps and institutional affiliations. 


\section{Authors and Affiliations}

\section{Carla Pérez $^{1,2}$ (D) Jean-François Boily ${ }^{1} \cdot$ Stina Jansson ${ }^{1} \cdot$ Tomas Gustafsson $^{3} \cdot$ Jerker Fick $^{1}$}

1 Department of Chemistry, Umeå University, 90187 Umeå, Sweden

2 Industrial Doctoral School, Umeå University, 90187 Umeå, Sweden
3 RISE Processum AB, Hörneborgsvägen 10, 89122 Örnsköldsvik, Sweden 